\title{
Influence of soy protein incorporation on acceptability and shelf-stability of sorghum based 'seviya'
}

\section{R. K. Reena Kumari and Jamuna Prakash* Department of Studies in Food Science and Nutrition, University on Mysore, Manasagangotri, Mysore, India jampr55@hotmail.com*}

Abstract: The objective of the investigation was to incorporate soy proteins to sorghum (Sorghum vulgare) flour in preparation of an Indian traditional deep fried product, Seviya and study the acceptability and shelf stability of the products. Seviya was prepared by incorporating soy protein concentrate at 10,15 and $20 \%$ levels to sorghum flour which served as base flour using traditional recipe. Products without soy served as controls. The prepared products were analyzed for fat uptake. They were stored in steel and PET (polyethylene terephthalate) containers at room and low temperatures and analyzed for free fatty acids. Acceptability was evaluated by 25 panel members using a score card. Results indicated that incorporation of soy protein increased fat uptake in the products. Fat content of control product was $27.5 \%$ whereas that of soy incorporated products ranged from 30.8 to $40.9 \%$. The free fatty acid levels, though showed a gradual increase with storage time, were not affected by soy incorporation. The initial free fatty acid levels were in the range of 0.243 $-0.465 \%$ and at the end of 21 days, they increased to $0.961-0.987 \%$. The products stored in PET containers at low temperature were better. The sensory quality of soy incorporated products was better in terms of higher sensory scores and storage of products did not lower the sensory quality of products.

Keywords: Fat absorption, free fatty acids, sensory quality, packaging containers.

Introduction

Among convenience foods, a major share of market belongs to the category of deep fried snacks. These are manufactured by organized sector as well as at smaller scale in cottage industries. The origin of most of these products can be traced to the traditional practices, wherein for want of better preservation techniques for fresh foods, fried foods naturally became a choice due to their shelf stability. The raw ingredients used for the deep fried snacks are mostly cereals or legumes, or a combination of both and in certain cases vegetables like potato, cassava and raw banana are also used. Advances made in this sector by modern food processors include use of additives and packaging materials to increase shelf stability of products. Use of alternative base materials like blends of unconventional cereals and legumes have also been tried at the laboratory level, though these have not been commercially exploited. Among the unconventional legumes, soybean has been tried for incorporation into various baked, fried or otherwise processed products (Pallavi et al., 1993; Kulkarni et al., 1994; Machewad et al., 2006). Soy bean are prized for unique properties namely, nutritional superiority with excellent protein content and quality and Research article CIndian Society for Education and Environment (iSee)

"Seviya"

http://www.indjst.org high quantity of fat and their functional behaviour in food systems, which improves the sensory quality of end product. Soy has been used as such in the form of full fat or defatted flour or as its components as protein isolate or concentrate. In all forms it tends to influence the quality of product (Lusas \& Riaz, 1995).

Seviya (also called as Sev), a deep fat fried, salted, and spiced snack item is popular throughout India. Traditionally, it is prepared from Bengal gram flour with additives such as spices, rice flour and sodium bicarbonate to impart crisp and crunchy texture to the fried product. Soy protein concentrate is one of the forms in which soy bean can be utilized and many studies have reported its incorporation in fried products. Incorporation of soy protein concentrate in preparation of seviya along with Bengal gram flour and sorghum flour has been tried by researchers. Sorghum is one among the many underutilized crops which are produced in India and other countries. Sorghum flour is used to make unleavened pan cake (roti) mainly in India especially in Karnataka and Maharashtra (Simmi \& Gurumukh, 1991; Pallavi et al., 1993; Ahluwalia et al., 1995; Anantha \& Daya, 2006; Machewad et al., 2006).

Rice bran oil has now been popularized as very healthy alternative cooking oil because of its nutritional quality and antioxidant content (Gopala Krishna, 2002; Gopala Krishna et al., 2006). Kahlon (1992) showed that rice bran oil in diet reduced LDL cholesterol and triglycerides and increased HDL cholesterol thus reducing the risk of coronary heart disease. Though rice bran oil has a nutty odour, it enhances the taste of food when used in processing or preparing snack foods, fried foods and crackers. Hence in the present study, rice bran oil was used as a frying medium in the preparation of snack 'seviya', because, rice bran is underutilized as a food material.

It was worthwhile to study the use of alternative flour for preparation of 'seviya', and also to investigate the effect of incorporation of soy protein concentrate on quality parameters of 'seviya'. Hence the study was planned to incorporate soy protein concentrate at different levels to sorghum flour based seviya and evaluate the product for fat absorption, shelf stability and sensory quality.

Materials and methods

The raw food material required for the preparation of seviya, namely sorghum (Sorghum vulgare) flour, omum (Trachyspermum ammi), salt and rice (Oryza sativa). Rice bran oil was used as the frying medium and was purchased from the local market. Soy protein concentrate was from Dupont-Solae Company. The chemicals used for the study were from Sd Fine Chemicals Ltd., Mumbai. 
Glass double distilled water was used for all analysis. All analysis was carried out in duplicate.

\section{Preparation of products}

The basic recipe involved sieving of the sorghum flour, mixing well with shortening (10\% rice bran oil, warmed to $\left.40^{\circ} \mathrm{C}\right)$, making a very soft dough with salt $(2 \%)$ and omum $(0.5 \%)$, extrusion through a mould into hot rice bran oil $\left(175^{\circ} \mathrm{C}\right)$ and removing the product after it gets a golden brown colour (cessation of bubbling signified the end of frying). The control product (P-1) was prepared only with sorghum flour. For experimental products, sorghum flour was replaced with 10\% (P-2), 15\% (P-3) and $20 \%(\mathrm{P}-4)$ of soy protein concentrate. In a typical batch, $500 \mathrm{~g}$ of flour and $500 \mathrm{ml}$ of oil were used for preparation of product. Each product was fried separately and fried oil was not reused for any of the product.

Analysis

The prepared dough was analyzed for its moisture content and the products were analyzed for their frying time, expansion ratio, fat uptake and free fatty acid contents (FFA). The FFA contents of fresh and fried oils were also analyzed.

Moisture content: The moisture content was determined as loss in weight of sample when heated under specific condition till a constant weight is achieved in a dry air oven at $60^{\circ} \mathrm{C}$ (AOAC, 1990).

Expansion ratio: A piece of sample was taken and the diameter measured using scale or screw gauge, to know the expansion volume of the product. The expansion ratio was calculated using the diameter of the orifice of the extrusion mould as percent increase.

Fat absorption: Fat absorption of the fried product was determined using solvent extraction by repeated extraction, oil with a petroleum ether, removing the solvent and weighing the oil extracted (AOAC, 1990).

Free Fatty Acid: Acid value of fat/oil is the number of milligrams of potassium hydroxide required to neutralize the free acids in known amount of sample under prescribed conditions and is expressed as free fatty acids (FFA) present in the sample (AOCS, 2000). For determination of FFA as indicative of keeping quality, the oil from the fried products was extracted in petroleum ether (boiling point, $60-80^{\circ} \mathrm{C}$ ) and subjected to analysis.

Storage study: The prepared products were stored at room temperature $\left(27^{\circ} \mathrm{C}\right)$ and in refrigerator $\left(5^{\circ} \mathrm{C}\right)$ using two different packaging materials i.e, PET (Polyethylene terephthalate) and container. All the products were analyzed for free fatty

\begin{tabular}{|c|c|c|c|c|c|}
\hline Tabiation & $\begin{array}{c}\text { Weight of } \\
\text { dough (g) }\end{array}$ & $\begin{array}{c}\text { Weight of } \\
\text { product (g) }\end{array}$ & $\begin{array}{c}\text { Expansion } \\
\text { ratio (\%) }\end{array}$ & $\begin{array}{c}\text { Frying } \\
\text { time (min) }\end{array}$ & $\begin{array}{c}\text { Moisture } \\
(\%)\end{array}$ \\
\hline P-1(Control) & 1260 & 696 & 25.0 & 30 & 58.04 \\
\hline P-2(SPC-10\%) & 1274 & 736 & 25.0 & 35 & 57.7 \\
\hline P-3(SPC-15\%) & 1416 & 797 & 25.0 & 40 & 59.0 \\
\hline P-4 (SPC-20\%) & 1434 & 962 & 25.0 & 50 & 61.0 \\
\hline
\end{tabular}

SPC: Soy protein concentrate

Table 2. Means scores for chemical and sensory analysis of products

\begin{tabular}{|c|c|c|c|c|c|}
\hline \multirow[t]{2}{*}{ Parameter } & \multicolumn{5}{|c|}{ Products } \\
\hline & $\mathrm{P}-1$ & $\mathrm{P}-2$ & P-3 & P-4 & $\mathrm{P}$ Value \\
\hline \multicolumn{6}{|l|}{ Chemical analysis } \\
\hline Fat absorption(\%) & $\begin{array}{l}27.5 \pm \\
0.199\end{array}$ & $\begin{array}{l}30.8 \pm \\
0.185\end{array}$ & $\begin{array}{l}36.7 \pm \\
0.143\end{array}$ & $\begin{array}{l}40.9 \pm \\
0.201\end{array}$ & - \\
\hline FFA in fried oil $(\%)$ & 0.196 & 0.221 & 0.246 & 0.258 & - \\
\hline FFA in product (\%) & 0.375 & 0.465 & 0.243 & 0.253 & - \\
\hline \multicolumn{6}{|l|}{ Sensory analysis } \\
\hline Appearance & $5.84 \pm 1.41$ & $6.48 \pm 1.42$ & $6.32 \pm 1.09$ & $7.16 \pm 1.83$ & $0.027^{*}$ \\
\hline Color & $5.80 \pm 1.57$ & $6.64 \pm 1.65$ & $6.32 \pm 1.22$ & $6.40 \pm 1.95$ & $0.336^{\mathrm{ns}}$ \\
\hline Texture & $6.16 \pm 1.97$ & $6.68 \pm 1.32$ & $6.28 \pm 1.64$ & $7.40 \pm 1.44$ & $0.039^{*}$ \\
\hline Aroma & $5.52 \pm 1.75$ & $6.12 \pm 1.45$ & $5.32 \pm 1.64$ & $6.60 \pm 1.85$ & $0.039^{*}$ \\
\hline Taste & $6.04 \pm 1.89$ & $6.52 \pm 1.96$ & $6.24 \pm 1.45$ & $7.80 \pm 1.85$ & $0.004^{\star *}$ \\
\hline
\end{tabular}

[a: FFA in fresh oil - $0.172 \%$ ]; P-1: Control product, P-2: $10 \%$ soy protein, $P$-3: $15 \%$ soy protein and $P-4: 20 \%$ soy protein. Values represent mean \pm standard deviation of sensory responses of 25 panelists. F- Ratio: $n s$ - not significant, ${ }^{*}-P \leq 0.05,{ }^{* *}-P \leq 0.01$. stainless steel necessitated higher use of water for preparing dough, the yzed for free fatty

acid contents on $0^{\text {th }}, 7^{\text {th }}, 14^{\text {th }}$ and $21^{\text {st }}$ days of storage. The packaging containers and duration of storage were chosen to mimic household storage of deep fried snack products.

thery analysis: The fresh and stored products were appearance, color, texture, aroma and taste with the help of a score card by 25 panel members. The panel members were students of the institution, who were familiar with the sensory analysis techniques. The sensory parameters. Coded samples were presented to panel members with a score card with a rating scale representing quality grade description as 1-2, poor; 3-4, fair; 5-6, good; 7-8, very good and 9-10, excellent (ISI and $14^{\text {th }}$ day respectively.

Statistical analysis: The data of sensory analysis were subjected to statistical analysis making use of Minitab statistical software. Mean and standard deviation were calculated individually for scores obtained for different variance was done to find out significant difference between quality attributes of seviya.

The results of the study are presented in Tables 1 to 4 and Fig 1. The dough parameters and yield of prepared products are given in Table 1. The moisture content of dough ranged from 57.7 to $61.0 \%$ for different products. Since incorporation of soy protein concentrate 1. Dough parameters and yield of prepared products 
had slightly higher level of moisture. Concurrently, the weight of the dough was also higher in products where higher amount of soy protein concentrate was used. It is said that the water absorption capacity of soy protein concentrate increases due to denaturation of proteins, because denatured proteins bind more water through exposure of the interior hydrophilic groups. The yield of product also varied depending upon the sample, it was least for control sample with $696 \mathrm{~g}$ and increased with increasing amount of soy protein concentrate. The highest increase was seen when the dough had $20 \%$ soy protein concentrate incorporated in it. The expansion of fried seviya strands was similar for all products at $25 \%$, which shows that incorporation of soy did not influence the expansion ratio. The frying time also varied depending upon the product and with increase in soy protein concentrate, more time was taken. This could also be due to the higher volume of the dough.

Many other workers also observed an increase in water absorption capacity of soy incorporated dough. Singh and Singh (1989) studied incorporation of defatted soy flour in preparation of seviya and its effect on product manufacturing, physicochemical and organoleptic characteristics. Bengal gram flour was blended with defatted soy flour at 10 to $30 \%$ level. During product preparation, the blends absorbed greater volumes of water than control for dough making. The results revealed that the hardness of the product as well as diameter and expansion ratio increased up to $15 \%$ level of defatted soy flour and thereafter decreased. Organoleptic characteristics revealed that product with $20 \%$ defatted soy flour was acceptable when compared to control.

The oil absorbed by the sorghum flour based seviya and the FFA content of fried rice bran oil is given in Table 2. The oil absorbed by the control product was $27.5 \%$ and showed a progressive increase with an increase in amount of soy protein concentrate. At 10\% level of incorporation the oil content was $30.8 \%$, which was more than $12 \%$ of the control value. On $15 \%$ level of soy protein incorporation, the oil absorbed was $17.3 \%$ higher than the control product, the value being $36.7 \%$. In the last

product with $20 \%$ soy protein, the oil absorption increased by $25 \%$ and it was $40.9 \%$. The FFA content of fried oil showed an increase with an increase in level of soy, the values ranged from 0.196 to $0.258 \%$. The FFA content in products, however, was slightly higher ranging from 0.243 to $0.465 \%$. It is reported that processing of soy protein concentrate increases the fat absorption capacity due to dissociation of proteins that occurs on heating and also due to denaturation which may occur on most of the non polar residue of protein molecules. Singh and Seetha (1993) examined the oil absorption and sensory properties of two products namely seviya and pakoda prepared from different grain legumes. The reproducibility of oil absorption of products was also determined. Results revealed that oil absorption of pakora ranged from 17.0 to $31.2 \%$ and that of seviya ranged between 31.5 to $35.6 \%$. Among the seviya prepared from different legume flours, the product prepared with chickpea was acceptable, followed by lentil, pigeon pea and green gram respectively. Addition of isolated starch fraction to the flour sample for seviya preparation showed increase with addition of $30 \%$ starch. The over all results revealed the flour particle size, starch and protein contents significantly influenced oil absorption

Fig. 1. Effect of storage on free fatty acid content of products

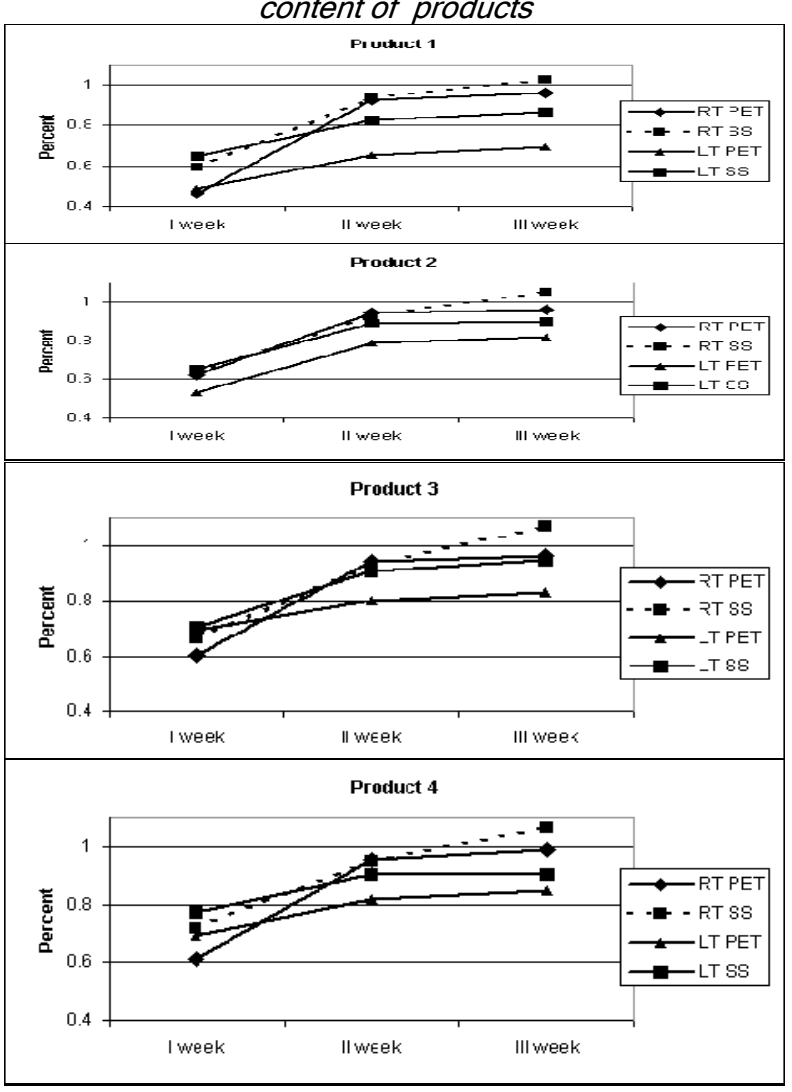

(Product 1: Control, Product 2: 10\% soy protein,

Product 3: $15 \%$ soy protein and Product 4: $20 \%$ soy protein; $R T$ : Room temperature $\left(27^{\circ} \mathrm{C}\right), \angle T:$ Low temperature $\left(5^{\circ} \mathrm{C}\right)$, PET: Polyethylene Terephthalate, SS: Stainless Steel)

"Seviya"

http://www.indjst.org of seviya.

The sensory and statistical analysis data of products on the day of preparation presented in Table 2 indicates that the control product obtained slightly lower score for appearance at 5.84 in comparison to experimental product which obtained between 6.32 and 7.16. The differences were not significant for the quality of color, though the control had slightly lower value than experimental. The quality of texture obtained almost similar scores for control product and with 10 and $15 \%$ soy protein incorporation. The product with $20 \%$ soy protein was given a high score of 7.4. For quality of aroma, the lowest score was obtained by the product with $15 \%$ soy protein followed by the control, $10 \%$ soy protein and $20 \%$ soy protein. The quality of taste followed a similar pattern for the first three products with scoring of 6.04 to 6.52 and a very high score of 7.8 for the product with $20 \%$ soy protein. The

Kumari \& Jamuna Prakash Indian J.Sci.Technol. 
scores were significantly different from each other $(P \leq 0.01)$. These results indicate that incorporation of soy protein concentrate helped to improve the sensory quality of sorghum based seviya. Interestingly the product made with $20 \%$ soy protein obtained highest scores followed by product made with $10 \%$ and $15 \%$ soy protein.

Table 3. Mean sensory scores of products stored in steel container

\begin{tabular}{|c|c|c|c|c|c|}
\hline \multirow{2}{*}{$\begin{array}{l}\text { Sensory } \\
\text { attributes }\end{array}$} & \multicolumn{5}{|c|}{$\begin{array}{ll} & \text { Products } \\
\end{array}$} \\
\hline & $\mathrm{P}-1$ & $\mathrm{P}-2$ & $\mathrm{P}-3$ & $\mathrm{P}-4$ & 'P' value \\
\hline \multicolumn{6}{|c|}{ Low Temperature $\left(5^{\circ} \mathrm{C}\right)$} \\
\hline \multicolumn{6}{|l|}{ I week } \\
\hline Appearance & $4.80 \pm 1.55$ & $5.72 \pm 1.59$ & $5.24 \pm 1.56$ & $6.92 \pm 1.78$ & $0.00^{* * *}$ \\
\hline Color & $4.80 \pm 1.44$ & $5.68 \pm 1.57$ & $5.24 \pm 1.61$ & $6.76 \pm 1.59$ & $0.00^{* * *}$ \\
\hline Texture & $5.64 \pm 1.87$ & $6.20 \pm 1.87$ & $5.52 \pm 1.66$ & $7.00 \pm 1.53$ & $0.013^{*}$ \\
\hline Aroma & $5.08 \pm 1.91$ & $5.64 \pm 1.75$ & $5.60 \pm 1.58$ & $6.44 \pm 1.76$ & $0.06^{\text {ns }}$ \\
\hline Taste & $5.12 \pm 1.81$ & $5.92 \pm 1.87$ & $5.72 \pm 1.67$ & $6.92 \pm 1.82$ & $2.69^{\text {ns }}$ \\
\hline \multicolumn{6}{|l|}{ II week } \\
\hline Appearance & $5.84 \pm 1.57$ & $6.04 \pm 1.51$ & $6.56 \pm 1.58$ & $6.08 \pm 1.38$ & $0.40^{\text {ns }}$ \\
\hline Color & $5.00 \pm 1.72$ & $5.68 \pm 1.67$ & $6.24 \pm 1.58$ & $5.92 \pm 1.76$ & $0.07^{\mathrm{ns}}$ \\
\hline Texture & $5.76 \pm 1.67$ & $5.84 \pm 1.48$ & $6.64 \pm 1.41$ & $6.52 \pm 1.60$ & $0.10^{\mathrm{ns}}$ \\
\hline Aroma & $5.44 \pm 1.39$ & $5.52 \pm 1.50$ & $6.36 \pm 1.52$ & $6.04 \pm 1.68$ & $0.12^{\text {ns }}$ \\
\hline Taste & $5.80 \pm 1.77$ & $5.96 \pm 1.37$ & $6.56 \pm 1.47$ & $6.32 \pm 1.76$ & $0.34^{\mathrm{ns}}$ \\
\hline \multicolumn{6}{|c|}{ Room Temperature $\left(27^{\circ} \mathrm{C}\right)$} \\
\hline \multicolumn{6}{|l|}{ I week } \\
\hline Appearance & $5.16 \pm 1.43$ & $5.84 \pm 1.46$ & $6.68 \pm 1.64$ & $6.44 \pm 1.42$ & $0.002^{* *}$ \\
\hline Color & $4.72 \pm 1.31$ & $5.44 \pm 1.20$ & $6.24 \pm 1.75$ & $6.04 \pm 1.25$ & $0.001^{* *}$ \\
\hline Texture & $5.68 \pm 1.61$ & $5.56 \pm 1.65$ & $6.64 \pm 1.52$ & $6.72 \pm 1.67$ & $0.018^{*}$ \\
\hline Aroma & $5.00 \pm 1.29$ & $5.32 \pm 1.49$ & $6.00 \pm 1.74$ & $6.12 \pm 1.63$ & $0.039^{*}$ \\
\hline Taste & $5.48 \pm 1.42$ & $5.80 \pm 1.72$ & $6.40 \pm 1.70$ & $6.48 \pm 1.60$ & $0.101^{\mathrm{ns}}$ \\
\hline \multicolumn{6}{|l|}{ II week } \\
\hline Appearance & $5.0 \pm 1.47$ & $5.32 \pm 1.57$ & $5.64 \pm 1.49$ & $4.62 \pm 1.57$ & $0.34^{\mathrm{nS}}$ \\
\hline Color & $4.64 \pm 1.29$ & $4.84 \pm 1.29$ & $5.24 \pm 1.48$ & $4.92 \pm 1.52$ & $0.51^{\mathrm{ns}}$ \\
\hline Texture & $5.04 \pm 1.37$ & $5.52 \pm 1.72$ & $6.08 \pm 1.55$ & $5.44 \pm 1.63$ & $0.15^{\mathrm{ns}}$ \\
\hline Aroma & $4.6 \pm 1.17$ & $5.12 \pm 1.33$ & $5.52 \pm 1.53$ & $5.20 \pm 1.50$ & $0.15^{\mathrm{ns}}$ \\
\hline Taste & $4.92 \pm 1.38$ & $5.48 \pm 1.47$ & $5.92 \pm 1.57$ & $5.48 \pm 1.70$ & $0.17^{\text {ns }}$ \\
\hline
\end{tabular}

P-1: Control product, $P-2$ : $10 \%$ soy protein, $P$-3: $15 \%$ soy protein and $P-4: 20 \%$

soy protein. Values represent mean \pm standard deviation of sensory responses of

25 panelists. F- Ratio: $n s$ - not significant, ${ }^{*}-P \leq 0.05,{ }^{* *}-P \leq 0.01,{ }^{* * *}-P \leq 0.001$.

Similar observations regarding products prepared with defatted soy flour have also been made by other workers. Ahluwalia et al. (1995) studied the preparation of traditional snacks by substituting base flour with defatted soy flour in three ready-to-eat snack foods like sev, sweet sev and murukku and evaluated the consumer acceptance of the products for various attributes. The water absorption studies revealed highest water absorption for defatted soy flour among soy, Bengal gram and refined wheat flour. It was stated that an increase in defatted soy flour proportionately increased water absorption. The data revealed that the crunchiness of the product increased on incorporation of defatted soy flour. The consumer acceptance studies resulted that soy incorporated products were acceptable. Simmi and Gurumukh (1991) aimed at preparing sev from blends of Bengal gram, defatted soy and rice flour and also studied their physicochemical and organoleptic characteristics. During dough preparation, blends absorbed greater amounts of water than control and the frying time of products increased with the level of dough moisture. And
Vol.2 No 4 (Apr. 2009)

ISSN: 0974- 6846 products made from blends were harder in texture control. Expansion ratio of products containing 25 to $30 \%$ defatted soy flour and 10 to $20 \%$ rice flour were higher than other preparations. Sensory evaluation revealed that product made from blends containing $10-15 \%$ soy and rice flour were similar to control with respect to overall acceptability

The FFA content of stored product for duration of 4 weeks is presented in Fig.1. The control and experimental products had a low FFA on the 0 day which increased gradually over a period of three weeks. The values for control and experimental products were also similar to each other. The product stored at room temperature in all categories had a slightly higher FFA than the one stored at low temperature. For the product stored in PET containers at room temperature, the values ranged from 0.961 to $0.987 \%$ at the end of $3^{\text {rd }}$ week, whereas for the product stored in stainless steel containers, values ranged from 1.028 to $1.070 \%$. This indicated that PET containers were better than steel containers. An increase in FFA content of products stored under refrigeration was also observed though the extent was lesser than what was seen at room temperature. These values for PET containers were 0.866 to $0.906 \%$. However, these values are very low when considered on the basis of product. This indicates that these products are chemically stable even after three weeks of storage. On analysis of variance it was found that there were no significant differences in the FFA content of any stored products (the ' $P$ ' values were for P-1, 0.775; P-2, 0.886; P-3, 0.985; and P-4, 0.981). Hence it can be said that as per the chemical analysis the products were stable for the duration of storage study and the storage conditions did not influence the FFA contents of products.

The sensory scores of products stored in steel containers are presented in Table 3 . The scores for appearance and color for products under refrigeration were 4.8 for the control product $(\mathrm{P}-1)$. The experimental products had higher scores ranging from 5.24 to 6.92 , which were statistically highly significantly different. The quality of texture were given low scores of 5.52 for the product with $15 \%$ soy protein (P-3) followed by control, $10 \%$ soy protein $(\mathrm{P}-2)$ and $20 \%$ soy protein $(\mathrm{P}-4)$, the differences were marginally significant. For the quality of aroma and taste, the scores ranged from 5.08 to 6.92 for all products. However, the trend of acceptability remained similar with control product scoring the least and the
Research article

(c)Indian Society for Education and Environment (iSee)
"Seviya"

http://www.indjst.org
Kumari \& Jamuna Prakash Indian J.Sci.Technol. 
experimental products scoring higher. The differences were not significant for these two qualities. The highest scores were given to the product with $20 \%$ soy protein (P4 ) for all quality attributes. The overall scores of products stored for $14^{\text {th }}$ days in refrigerator in steel containers for all quality attributes ranged between 5 and 6.64 and were statistically not significant. For all quality attributes the sample with $15 \%$ soy protein had higher scores and the control had the least scores. Table 4. Mean sensory scores of products stored in PET container

\begin{tabular}{|c|c|c|c|c|c|}
\hline \multirow{2}{*}{$\begin{array}{l}\text { Sensory } \\
\text { attributes }\end{array}$} & \multicolumn{5}{|l|}{ Products } \\
\hline & $\mathrm{P}-1$ & $\mathrm{P}-2$ & P-3 & P-4 & 'P' value \\
\hline \multicolumn{6}{|c|}{ Low Temperature $\left(5^{\circ} \mathrm{C}\right)$} \\
\hline \multicolumn{6}{|l|}{ I week } \\
\hline Appearance & $5.00 \pm 1.65$ & $5.88 \pm 1.59$ & $6.80 \pm 1.38$ & $7.00 \pm 1.50$ & $0.00^{\star * \star}$ \\
\hline Color & $5.24 \pm 1.39$ & $5.64 \pm 1.44$ & $6.56 \pm 1.64$ & $6.48 \pm 1.66$ & $0.005^{\star *}$ \\
\hline Texture & $5.40 \pm 1.87$ & $6.12 \pm 1.48$ & $7.00 \pm 1.68$ & $7.12 \pm 1.30$ & $0.00^{* \star *}$ \\
\hline Aroma & $5.44 \pm 1.53$ & $5.80 \pm 1.32$ & $6.32 \pm 1.49$ & $6.60 \pm 1.44$ & $0.026^{*}$ \\
\hline Taste & $5.84 \pm 1.89$ & $6.28 \pm 1.45$ & $6.92 \pm 1.55$ & $7.24 \pm 1.64$ & $0.014^{*}$ \\
\hline \multicolumn{6}{|l|}{ II week } \\
\hline Appearance & 5.52 & 6.16 & $5.60 \pm 1.47$ & $\begin{array}{c}5.80 \pm 1 . \\
33\end{array}$ & $0.36^{\mathrm{ns}}$ \\
\hline Color & $5.36 \pm 1.29$ & $6.04 \pm 1.59$ & $5.80 \pm 1.13$ & $6.08 \pm 1.41$ & $0.24^{\mathrm{ns}}$ \\
\hline Texture & $6.12 \pm 1.64$ & $6.36 \pm 1.38$ & $6.24 \pm 1.3$ & $6.52 \pm 1.45$ & $0.79^{\text {ns }}$ \\
\hline Aroma & $5.44 \pm 1.39$ & $5.24 \pm 1.14$ & $5.68 \pm 1.26$ & $6.12 \pm 1.31$ & $0.10^{\text {ns }}$ \\
\hline Taste & $5.60 \pm 1.32$ & $5.72 \pm 1.11$ & $5.80 \pm 1.23$ & $6.16 \pm 1.69$ & $0.53^{\mathrm{ns}}$ \\
\hline \multicolumn{6}{|c|}{ Room Temperature $\left(27^{\circ} \mathrm{C}\right)$} \\
\hline \multicolumn{6}{|l|}{ I week } \\
\hline Appearance & $5.72 \pm 1.56$ & $5.96 \pm 1.40$ & $6.00 \pm 1.36$ & $6.28 \pm 2.03$ & $0.691^{\mathrm{nS}}$ \\
\hline Color & $5.88 \pm 1.73$ & $6.00 \pm 1.55$ & $6.08 \pm 1.38$ & $6.28 \pm 1.73$ & $0.851^{\mathrm{nS}}$ \\
\hline Texture & $6.40 \pm 1.85$ & $6.08 \pm 1.41$ & $6.36 \pm 1.47$ & $5.8 \pm 1.65$ & $0.805^{\mathrm{ns}}$ \\
\hline Aroma & $6.08 \pm 1.84$ & $5.56 \pm 1.10$ & $5.8 \pm 1.36$ & $6.32 \pm 1.43$ & $0.250^{\text {ns }}$ \\
\hline Taste & $6.28 \pm 1.78$ & $6.08 \pm 1.70$ & $6.40 \pm 1.50$ & $6.80 \pm 1.41$ & $0.464^{\mathrm{ns}}$ \\
\hline \multicolumn{6}{|l|}{ II week } \\
\hline Appearance & $5.32 \pm 1.32$ & $5.76 \pm 1.45$ & $5.52 \pm 1.10$ & $5.40 \pm 1.62$ & $0.711^{\mathrm{nS}}$ \\
\hline Color & $5.04 \pm 1.68$ & $5.48 \pm 1.81$ & $5.52 \pm 1.45$ & $5.40 \pm 1.70$ & $0.742^{\mathrm{ns}}$ \\
\hline Texture & $5.32 \pm 1.35$ & $5.88 \pm 1.63$ & $6.00 \pm 1.30$ & $5.80 \pm 1.65$ & $0.414^{\mathrm{nS}}$ \\
\hline Aroma & $4.64 \pm 1.13$ & $5.04 \pm 1.11$ & $5.68 \pm 1.12$ & $5.32 \pm 1.52$ & $0.031^{*}$ \\
\hline Taste & $5.24 \pm 1.53$ & $5.28 \pm 1.31$ & $6.24 \pm 1.21$ & $5.84 \pm 1.78$ & $0.061^{\mathrm{ns}}$ \\
\hline
\end{tabular}

The mean sensory score of the product stored at room temperature showed significant differences for appearance and color $(P \leq 0.01)$ and for texture and aroma $(P \leq 0.05)$. There was no difference in the quality of taste. Highest scores were given for appearance and colour for $\mathrm{P}-3$ product at 6.68 and 6.24 respectively. This was followed by P-4, P-2 and P-1. For the quality of texture and aroma the differences were marginal. The product with $10 \%$ soy protein obtained least for texture followed by control, P-3 and P-4 products. For aroma, it was least for control, increasing with increasing levels of soy protein incorporation in other products. The taste quality was not different among products the scores ranging from 5.8 to 6.48 . The scores for products stored at room temperature in steel container after 2 weeks exhibited a different results. There were no significant differences between the sensory quality of any product tested for any attributes. For appearance and color the scores ranged from 4.62 to
Vol.2 No 4 (Apr. 2009)

ISSN: 0974- 6846
5.64 , for texture they were between 5.04 to 6.08 , for aroma 4.6 to 5.52 and for taste 4.96 to 5.92 respectively.

The product stored in PET container was also analyzed for sensory quality and the results are presented in Tables 4. For the products stored at low temperature after one week of storage, the responses varied between fair and good for different attributes, the appearance was given a score of 5 for control and the scores increased gradually as the incorporation of soy protein concentrate increased. The differences between the scores were highly significant on application of ANOVA. For the quality of color the order of scores followed was lowest for control and higher for soy incorporated products. The quality of texture also differed significantly with the last two products obtaining higher scores. Only marginal differences were observed in taste and aroma of all samples. For both these qualities the scores increased as the incorporation of soy protein increased, the highest score was given for $20 \%$ soy protein product as for other attributes. After two weeks of storage under similar conditions, the products were given scores which did not differ significantly. Under this storage conditions, the $20 \%$ soy protein concentrate incorporated sample was found to be superior for color, texture, aroma and taste, whereas sample with $10 \%$ soy protein incorporated sample was superior in appearance. Because of no statistical difference, it can be said that all products were acceptable.

The range of scores obtained for different sensory attributes for products stored in PET containers at room temperature were as follows - appearance 5.72 to 6.28 , color 5.88 to 6.28 , texture 6.08 to 6.48 , aroma 5.56 to 6.32 and taste 6.08 to 6.80 . Unlike other samples some of the soy protein incorporated products here scored lesser than control. However, there were no significant differences between any sensory responses. The scores for sensory quality of products stored for two weeks in PET containers under room temperature exhibited lower values compared to the samples stored in refrigerator. The values obtained were almost similar for all samples indicating that the product wise differences were not seen. On quality grade scale, the acceptability could be categorized as fair for appearance and color, texture, taste and aroma for all products with the exception of color, texture, taste and aroma attributes of $15 \%$ soy protein incorporated product which was graded as good. These scores on the whole were superior to the scores obtained by product stored in steel container under the same conditions.
Research article

CIndian Society for Education and Environment (iSee)
"Seviya"

http://www.indjst.org
Kumari \& Jamuna Prakash Indian J.Sci.Technol. 
The major observations of the study can be summarized as follows: The incorporation of soy protein concentrate definitely increased the acceptability of product for all quality attributes. Varying responses were obtained for different levels of incorporation as the products incorporated with 10,15 and $20 \%$ soy protein concentrate obtained higher score in some categories of stored products. For storage, PET container was definitely better than steel, which can be attributed to its low moisture and air ingress. Same way, the low temperature in the experiment was found to be better. This can be attributed to lower deteriorative changes taking place in product which can also be correlated with the result of free fatty acid analysis wherein the product stored at low temperature had a low free fatty acid formation.

References

1. Ahluwalia T, Usha MS and Pratima A (1995) Traditional snack foods from defatted soy flour textural properties and consumers acceptance. Bev. Food World. 23(5), 22-27.

2. Anantha D and Daya SS (2006) Organoleptic evaluation of snacks prepared from soy flour. Bev. Food World. 34(8), 29-30.

3. AOAC (1990) Official methods of analysis. $15^{\text {th }}$ ed. Association of Official Analytical Chemists, Washington, Virginia.

4. AOCS (2000). Free fatty acids and peroxide value. Approved methods of the American Association of Cereal Chemists (Vol 2, $10^{\text {th }}$ edn), American Oil Chemists Society, Illinois: Method No. 58-15 (p: 1 of 2) and 58-16 (p: 1 of 3).

5. Gopala Krishna AG (2002) Nutritional components of rice bran oil in relation to processing. Lipid Tech. 14, 80-84.

6. Gopala Krishna AG, Hemakumar $\mathrm{KH}$ and Khatoon S (2006) Study on composition of rice bran oil and its higher free fatty acids value. J. Amer. Oil Chem. Soc. 83, 117-120.

7. ISI (1972) Guide for sensory evaluation of foods. Indian Standard Institution, New Delhi, 28.

8. Kahlon TS, Saunders RM, Sayrem RN, Chow FI, Chlu MN and Betschart AA (1992) Cholesterol lowering effect of rice bran oils fractions in hypercholesterolmic hamsters. Cereal Chem. 69, 485-489.

9. Kulkarni SG, Manan JK and Shukla IC (1994) Studies on deep fat fried sevian made from rice flour and colocasia. J. Food Sci. Technol. 34, 207-210.

10. Lusas EW and Riaz MN (1995) Soy protein products, processing and use. J. Nutri. 125: 573S-580S.

11. Machewad GM, Syed HM, Sakhale BK, Pawar VD and Agarkar BS (2006) Studies on preparation and qualities of chakli using sorghum-soybean-chickpea composite flour. Bev. Food World. 34(8), 68-32.

12. Pallavi S, Usha MS, Pratima A and Chauhan GS (1993) Defatted soy flour substitution in some traditional foods-l: Effect on sensory characteristics. Bev. Food World. 21(7), 7-10.

13. Simmi D and Gurumukh S (1991) Studies on sev preparation from blends of Bengal gram flour, defatted soy flour and rice flour. Bev. Food World. 19(4), 18-21.

14. Singh RP and Singh G (1989) Use of defatted soy flour in sev preparation. Bev. Food World. 16(2), 2224.

15. Singh $U$ and Seetha $R$ (1993) Oil absorption and sensory properties of a snack food from chickpea genotypes. J. Food Sci. 58 (4), 853-855. 